\title{
Tetracycline Resistance and Presence of Tetracycline Resistance Determinants tet(V) and tap in Rapidly Growing Mycobacteria from Agricultural Soils and Clinical Isolates
}

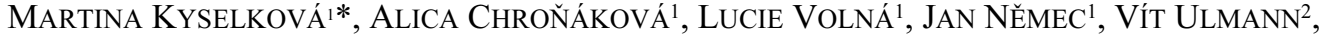 \\ JOSEF SCHARFEN ${ }^{3,4}$, and DANA ELHOTTOVÁ ${ }^{1}$ \\ ${ }^{1}$ Biology Centre of the Academy of Sciences of the Czech Republic, Institute of Soil Biology, České Budéjovice, Czech \\ Republic; ${ }^{2}$ Institute of Public Health, Ostrava, Czech Republic; ${ }^{3}$ Institute of Clinical Microbiology, Charles University \\ in Prague, Faculty of Medicine in Hradec Králové and University Hospital Faculty of Medicine in Hradec Králové; and \\ ${ }^{4}$ National Reference Laboratory for Pathogenic Actinomycetes, Dept. Medical Microbiology and Immunology, Regional \\ Hospital Trutnov, Inc., Trutnov, Czech Republic
}

(Received February 1, 2012—Accepted April 2, 2012—Published online May 17, 2012)

Rapidly growing mycobacteria (RGM) inhabit soil and water but certain strains represent a health risk for human and animals. Both clinical and soil RGM may be under selection pressure for resistance to tetracycline (TET) antibiotics, since tetracyclines are administrated to humans and farm animals, and TET residues enter soil through manuring; however, resistance to TET and the presence of TET-resistance genes have been assessed only in clinical isolates. We were therefore interested in comparing soil and clinical RGM in terms of TET resistance and the presence of TETresistance genes. We used 44 RGM from grasslands with different exposure to animal manure, and 38 clinical RGM from Czech hospitals. There was no difference between the clinical and soil isolates in TET resistance, with $>50 \%$ resistant isolates in both groups. $\operatorname{otr}(\mathrm{A}), \operatorname{otr}(\mathrm{B}), \operatorname{tet}(\mathrm{K}), \operatorname{tet}(\mathrm{L}) \operatorname{or} \operatorname{tet}(\mathrm{M})$ were not detected in any soil or clinical isolate. In contrast, most isolates harbored tet $(\mathrm{V})$ and tap, both encoding mycobacterial efflux pumps, including species where these genes have never been evidenced before. The phylogeny of tet $(\mathrm{V})$ correlated with isolates' BOX-PCR profiles, suggesting that this gene evolved along with mycobacterial genomes as a part of the intrinsic resistome. In certain cases, tet $(\mathrm{V})$ and/or tap were found in TET-sensitive isolates, or inversely, were not found in resistant strains. Concluding, intrinsic efflux pumps may be more important for TET resistance than horizontally transferred genes in both soil and clinical RGM. Their simple presence, however, does not attest to resistance, and therefore their diversity, function and expression merit further research.

Key words: efflux pump, rapidly growing Mycobacterium, tetracycline resistance, tap, tet(V)

Rapidly growing mycobacteria (RGM) are common inhabitants of soil and water. In past decades, they have been increasingly recognized as a cause of human and animal diseases $(15,25)$. These include respiratory infections, a spectrum of hard and soft tissue infections or bacteremia in immunocompromised patients, as well as infections related to injuries in healthy individuals $(8,29,48)$. The natural and man-transformed environment is an important reservoir of RGM, from which transmission to humans occurs (50). Although the direct relationship between an environmental source and clinical disease is difficult to evidence, several RGM outbreaks have been associated with the exposure to soil and water $(2,16)$, including drinking water (49).

The prevention and treatment of infections due to RGM is not trivial because of their high resistance to disinfectants and antibiotics. One group of antibiotics used in the therapy of RGM infections is the tetracyclines (TET) such as doxycycline and minocycline (15). Mycobacteria in general have intrinsic resistance to many antibiotics ensured by the composition of their cell wall and the presence of several multidrug efflux pumps $(33,36)$. Tetracycline/multidrug

\footnotetext{
* Corresponding author. E-mail: martinak@upb.cas.cz;

Tel: +420387 775 771; Fax: +420385310133.
}

efflux pumps Tet(V) and Tap may belong to this intrinsic resistome as they have been so far found only in certain RGM species $(17,22)$.

Acquired resistance is not often seen in Mycobacterium; however, Pang et al. (38) reported four genes conferring TET resistance in clinical RGM that have been most probably horizontally transferred from other bacteria. These included $\operatorname{otr}(\mathrm{A})$ and $\operatorname{otr}(\mathrm{B})$, self-protection genes from the oxytetracycline producer Streptomyces rimosus (9), and $\operatorname{tet}(\mathrm{K})$ and $\operatorname{tet}(\mathrm{L})$, low-G+C-content genes encoding tetracycline efflux pumps, which are typically found in Firmicutes (Streptococcus, Staphylococcus, Enterococcus) but also in some Gram-negative bacteria (40). More recently, tet(M), a widely distributed gene with a low $\mathrm{G}+\mathrm{C}$ content encoding a ribosomal protection protein, was found in a humanassociated Mycobacterium sp. (41).

Resistance to TET and the presence of TET-resistance genes in RGM have been studied in clinical isolates only; however, soil is an important reservoir of TET resistance genes, both indigenous (14) and introduced by manuring (10). In addition, tetracycline residues are detectable in manured soil (10), which may help select resistant strains. Soildwelling RGM may therefore represent an important pool of TET resistance genes. 
The main objective of this study was to compare soil and clinical isolates of RGM (both from the Czech Republic) in terms of the resistance to tetracycline and presence of seven TET-resistance determinants. The genome relatedness of isolates was assessed with BOX-PCR as a high correlation exists between BOX-PCR fingerprints and DNA-DNA homology data $(31,39,51)$. 16S rRNA gene sequencing was performed to identify the isolates. Resistance to TET was assessed with the agar disk diffusion method, and the presence of TET resistance genes that were previously described in clinical RGM, i.e., $\operatorname{otr}(\mathrm{A}), \operatorname{otr}(\mathrm{B}), \operatorname{tet}(\mathrm{K}), \operatorname{tet}(\mathrm{L}), \operatorname{tet}(\mathrm{M}), \operatorname{tet}(\mathrm{V})$ and the multi-drug efflux pump-encoding gene tap, was checked with PCR and sequencing. The phylogeny of tet $(\mathrm{V})$ was compared to the BOX-PCR profiles of isolates.

\section{Materials and Methods}

\section{Soil isolates of rapidly-growing mycobacteria}

Soil RGM were isolated from four sites of three farms located in South Bohemia, Czech Republic in 2007-2010 (Table S1). The distance between farms was up to $10 \mathrm{~km}$. Farm 1 is a conventional farm engaged in intensive pig fattening, where animals (about 2,000) are commonly treated with antibiotics including chlortetracycline and doxycycline. At Farm 1, we sampled a permanent grassland, which had been periodically manured ( $2-3$ times per year) with pig slurry for the previous 30 years (designated Site 1). At Farm 2, which is a small family farm in a neighborhood community, we sampled permanent grassland that had not been manured for the previous 20 years (Site 2). Samples were taken from Site 1 and Site 2 in June 2007 and 2009. Farm 3 has performed outdoor cattle husbandry since 1993 and is an organic farm without the application of antibiotics. Two sites (Site 3 and Site 4) were sampled at Farm 3 in May 2010. Site 3 is part of the pasture where cattle stay from October until May. It is highly impacted by the cattle, i.e., the soil is highly enriched with excrement and vegetation cover is damaged (28). Site 4 is a pasture with low impact by the cattle and preserved vegetation. At each site, soil from a depth of about $10-30 \mathrm{~cm}$ (under the plant roots) was sampled with a sterile spade from three points 5-20 m apart. The soil from the three points was mixed and sieved. Soils were kept at $4^{\circ} \mathrm{C}$ during transport to the laboratory and prior to the accompanying physicochemical and microbial analyses (Table $\mathrm{S} 1)$. RGM were isolated from soil using the $\mathrm{NaOH} /$ malachite green/ cycloheximide decontamination method of Iivanainen (27) or the olive oil/SDS decontamination method (with $10 \mathrm{mg}$ SDS per plate) of Yamamura and Harayama (53) or directly on Tryptic-Soy agar plates with $25 \mathrm{mg} \mathrm{L}^{-1}$ chlortetracycline (2 isolates from 2007) (Table S2).

\section{Clinical isolates of rapidly-growing mycobacteria}

Clinical RGM were obtained from the National Reference Laboratory for Pathogenic Actinomycetes, Regional Hospital in Trutnov, and from the Institute of Public Health, Ostrava, Czech Republic. They were isolated in 2006-2011 from various samples such as abscess, urine, hemoculture, corneal ulcer and sputum from 18 hospitals in the Czech Republic (Table S3). Their role in the etiology of infection was confirmed in isolates from abscesses, hemocultures and corneal ulcers. Incidental isolates from sputa of patients screened for Mycobacterium tuberculosis without clinical and imaging correlates were usually colonizers, with the exception of Mycobacterium chelonae OS10 associated with a pulmonary disease in a 47-year-old patient.

\section{Susceptibility to tetracycline}

Susceptibility to tetracycline was assessed with a disc diffusion test (26). Pure isolates were first grown on M2 (42) or Šula's medium (43) with the addition of $1.5 \%$ agar, at $28^{\circ} \mathrm{C}$ for 5 to $7 \mathrm{~d}$. A homogenous bacterial suspension was prepared by vortexing
(Vortex-Genie2; Mo Bio Laboratories, Carlsbad, CA, USA) and ultrasonication (Ultrasonic Compact Cleaner UC 006DM1, Tesla, Czech Republic) of several colonies in $4 \mathrm{~mL}$ of sterile $0.9 \% \mathrm{NaCl}$. The turbidity of the suspension was adjusted with sterile $0.9 \% \mathrm{NaCl}$ to match the McFarland standard 0.5 (densitometer DEN-1; Biosan, Latvia) (52). The suspension was spread onto Mueller-Hinton agar medium (Bio-Rad Laboratories, Hercules, CA, USA) supplied with TET disks $(30 \mu \mathrm{g}$; Bio-Rad). Inhibition zone diameters were recorded after $5 \mathrm{~d}$ of incubation at $28^{\circ} \mathrm{C}$. The ranked zone sizes of environmental and clinical strains were statistically compared with Wilcoxon rank sum test in R (http://www.r-project.org). Strains OS18, OS2/1, OS2/2 and OS2/4 did not grow on Mueller-Hinton agar and disc diffusion analysis was therefore performed on Šula's medium. These strains were not included in the statistical analysis.

\section{BOX-PCR genomic DNA fingerprints}

Prior to PCR amplification, cell lysates were prepared as follows. One bacteriological loop of mycobacterial biomass grown on an agar plate was resuspended in $100 \mu \mathrm{L}$ ultra-pure water. The suspensions were then boiled three times (water bath, $100^{\circ} \mathrm{C}$ ) for 5 min and frozen at $-20^{\circ} \mathrm{C}$ for $1 \mathrm{~h}$. The lysates were stored at $-20^{\circ} \mathrm{C}$ and $1 \mu \mathrm{L}$ of the lysates was used as a template for PCR.

DNA amplification followed the procedure of Lanoot et al. (31) using the BOXA1R primer (5'-CTACGGCAAGGCGACGCT GACG-3') (51). PCR products $(20 \mu \mathrm{L})$ were separated on $20 \times 20$ $\mathrm{cm}$ gels using $130 \mathrm{~V}, 400 \mathrm{~mA}$ for $240 \mathrm{~min}$ in $1 \times \mathrm{TBE}$ buffer (Tris base $53 \mathrm{~g}$, boric acid $27.5 \mathrm{~g}, 0.5 \mathrm{M}$ EDTA $20 \mathrm{ml}, \mathrm{pH} 8.0$ ). The gels were stained for $30 \mathrm{~min}$ in a $1 \times \mathrm{TBE}$ bath supplemented with ethidium bromide $\left(1 \mathrm{mg} \mathrm{L}^{-1}\right)$. A photograph of the gel was stored as a TIFF file through a CCD coupled camera using Photo-Doc software (Vilber-Lourmat, Marne-la-Vallée, France). Gels were imported into the software package GelCompar II (Applied Maths, Sint-MartensLatem, Belgium) and similarity matrices of densitometric curves of the gel tracks were calculated using the Pearson correlation coefficient followed by dendogram construction using the UPGMA algorithm. We used the limit of $70 \%$ similarity to define distinct BOX-PCR groups (12).

\section{Isolate identification}

Clinical strains TR-1378, OS1, OS8, OS9, OS10, OS11, OS13, OS21, OS24, OS25, OS28, OS30, OS2/7 and OS2/8 were identified with the GenoType Mycobacterium CM (Common Mycobacteria) Test based on DNA Strip technology (Hain Lifescience, Nehren, Germany). The 16S rRNA gene of the clinical strain TR-1380 was sequenced by the commercial system MicroSeq 500 16S rDNA Bacterial Identification Kit (Applied Biosystems, Foster City, CA, USA). Both analyses were performed at the Institute of Public Health Ostrava (Czech Republic).

The remaining clinical isolates and at least one soil isolate from each BOX-PCR group were identified with $16 \mathrm{~S}$ rRNA gene amplification using universal bacterial primers (21) pA (5'AGAGTTTGATCCTGGCTCAG-3') and $\mathrm{pH}$ (5'-AAGGAGGT GATCCAGCCGCA-3'), and sequencing. The total volume of PCR reactions was $50 \mu \mathrm{L}$. The final reaction mixtures contained (final concentrations) Expand Long Template PCR System Buffer \#1 (Roche Applied Science, Mannheim, Germany; 1×), dNTPs (Fermentas, Thermo Fisher Scientific, Waltham, MA, USA; $0.3 \mathrm{mM}$ each), primers (500 nM each) and Expand Long Template

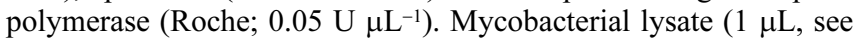
above) served as a template. Thermal cycling was performed as follows: Initial denaturation at $94^{\circ} \mathrm{C}$ for 2 minutes; followed by 35 cycles of denaturation $\left(94^{\circ} \mathrm{C} / 15 \mathrm{~s}\right)$, annealing $\left(61^{\circ} \mathrm{C} / 30 \mathrm{~s}\right)$ and extension $\left(68^{\circ} \mathrm{C} / 45 \mathrm{~s}\right.$; the duration of extension was prolonged to $90 \mathrm{~s}$ after the first ten cycles); and final extension at $68^{\circ} \mathrm{C}$ for $7 \mathrm{~min}$. Amplified 16S rRNA genes were cleaned-up with the GenElute PCR Clean-Up Kit (Sigma-Aldrich, St. Louis, MO, USA) and sequenced using the primers $\mathrm{pA}, \mathrm{pH}$ and $519 \mathrm{r}(21,30)$.

The obtained 16S rRNA gene sequences were edited by Bioedit 7.0.4.1 software (23) and assembled using SeqMAN (DNAStar, 
Table 1. Primers and PCR conditions used for tetracycline resistance gene amplification

\begin{tabular}{|c|c|c|c|c|c|}
\hline Gene & Primers & Primer sequences 5'-3' (Reference) & PCR cycles & $\begin{array}{l}\text { Amplicon } \\
\text { (bp) }\end{array}$ & Positive control \\
\hline $\operatorname{otr}(\mathrm{A})$ & $\begin{array}{l}\operatorname{otr}(\mathrm{A})(\mathrm{F}) \\
\operatorname{otr}(\mathrm{A})(\mathrm{R})\end{array}$ & $\begin{array}{l}\text { GAACACGTACTGACCGAGAAG } \\
\text { CAGAAGTAGTTGTGCGTCCG } \\
\text { (37) }\end{array}$ & $\begin{array}{l}5 \mathrm{~min} / 95^{\circ} \mathrm{C} ; 35 \times\left(1 \mathrm{~min} / 94^{\circ} \mathrm{C},\right. \\
\left.30 \mathrm{~s} / 60^{\circ} \mathrm{C}, 30 \mathrm{~s} / 72^{\circ} \mathrm{C}\right) ; 5 \mathrm{~min} / \\
72^{\circ} \mathrm{C}\end{array}$ & 778 & $\begin{array}{l}\text { Streptomyces rimosus subsp. rimosus } \\
\text { DSMZ } 40260 \text { (ATTC 10970) }\end{array}$ \\
\hline $\operatorname{otr}(\mathrm{B})$ & $\begin{array}{l}\operatorname{otr}(\mathrm{B})(\mathrm{F}) \\
\operatorname{otr}(\mathrm{B})(\mathrm{R})\end{array}$ & $\begin{array}{l}\text { CCGACATCTACGGGCGCAAGC } \\
\text { GGTGATGACGGTCTGGGACAG } \\
\text { (37) }\end{array}$ & $\begin{array}{l}5 \mathrm{~min} / 95^{\circ} \mathrm{C} ; 35 \times\left(1 \mathrm{~min} / 94^{\circ} \mathrm{C}\right. \\
\left.1 \mathrm{~min} / 68^{\circ} \mathrm{C}, 1 \mathrm{~min} / 72^{\circ} \mathrm{C}\right) ; 7 \\
\min / 72^{\circ} \mathrm{C}\end{array}$ & 947 & $\begin{array}{l}\text { Streptomyces rimosus subsp. rimosus } \\
\text { DSMZ } 40260 \text { (ATTC 10970) }\end{array}$ \\
\hline tap & $\begin{array}{l}\text { Tap1 } \\
\text { Tap2 }\end{array}$ & $\begin{array}{l}\text { GTCGCGTTCCCGTGGCTGGT } \\
\text { CGATACCGGGGCCGACGATG } \\
(22)\end{array}$ & $\begin{array}{l}10 \mathrm{~min} / 94^{\circ} \mathrm{C} ; 35 \times\left(1 \mathrm{~min} / 94^{\circ} \mathrm{C},\right. \\
\left.30 \mathrm{~s} / 68^{\circ} \mathrm{C}, 30 \mathrm{~s} / 72^{\circ} \mathrm{C}\right) ; 3 \mathrm{~min} / \\
72^{\circ} \mathrm{C}\end{array}$ & 400 & $\begin{array}{l}\text { Mycobacterium fortuitum TR-1242 } \\
\text { (this study) }\end{array}$ \\
\hline $\begin{array}{l}\operatorname{tet}(\mathrm{K}) \text { and } \\
\operatorname{tet}(\mathrm{L})\end{array}$ & $\begin{array}{l}\text { tetKL-FW } \\
\text { tetKL-RV }\end{array}$ & $\begin{array}{l}\text { TTACCTGATATTGCAA } \\
\text { GACCAATGAATATAAT } \\
\text { (this study) }\end{array}$ & $\begin{array}{l}5 \mathrm{~min} / 95^{\circ} \mathrm{C} ; 35 \times\left(30 \mathrm{~s} / 94^{\circ} \mathrm{C}\right. \\
\left.30 \mathrm{~s} / 40^{\circ} \mathrm{C}, 30 \mathrm{~s} / 72^{\circ} \mathrm{C}\right) ; 3 \mathrm{~min} / \\
72^{\circ} \mathrm{C}\end{array}$ & 397 & $\begin{array}{l}\text { Staphylococcus haemolyticus } \mathrm{CB}-\mathrm{N} \\
\text { (tet }(\mathrm{K}) \text {; this study) and Staphylococcus } \\
\text { aureus pSTS9-like (tet(L); } 1)\end{array}$ \\
\hline $\operatorname{tet}(\mathrm{M})$ & $\begin{array}{l}\text { TetM-FW } \\
\text { TetM-RV }\end{array}$ & $\begin{array}{l}\text { ACAGAAAGCTTATTATATAAC } \\
\text { TGGCGTGTCTATGATGTTCAC } \\
\text { (6) }\end{array}$ & $\begin{array}{l}4 \mathrm{~min} / 94^{\circ} \mathrm{C} ; 35 \times\left(20 \mathrm{~s} / 94^{\circ} \mathrm{C}\right. \\
\left.30 \mathrm{~s} / 52.3^{\circ} \mathrm{C}, 1 \mathrm{~min} / 72^{\circ} \mathrm{C}\right) ; 7 \\
\min / 68^{\circ} \mathrm{C}\end{array}$ & 171 & $\begin{array}{l}\text { Plasmid pAT101 that carries tet(M) } \\
\text { gene from Streptococcus transposon } \\
\text { Tn1545 (34) }\end{array}$ \\
\hline $\operatorname{tet}(\mathrm{V})$ & $\begin{array}{l}\text { tetV-FW } \\
\text { tetV-RV }\end{array}$ & $\begin{array}{l}\text { GCCTACGGTTTCATCCTGGC } \\
\text { CGAGACCACCTTCGACAGCG } \\
\text { (this study) }\end{array}$ & $\begin{array}{l}7 \mathrm{~min} / 95^{\circ} \mathrm{C} ; 35 \times\left(1 \mathrm{~min} / 94^{\circ} \mathrm{C},\right. \\
\left.15 \mathrm{~s} / 65^{\circ} \mathrm{C}, 30 \mathrm{~s} / 72^{\circ} \mathrm{C}\right) ; 5 \mathrm{~min} / \\
72^{\circ} \mathrm{C}\end{array}$ & 351 & $\begin{array}{l}\text { Mycobacterium sp. Site2-2C (this } \\
\text { study) }\end{array}$ \\
\hline
\end{tabular}

Madison, WI, USA) (45). The edited sequences were compared against the database of type strains Ez-Taxon Database (http:// www.eztaxon.org) (11) to retrieve the most relative species.

\section{Detection of tetracycline resistance genes}

The presence of tetracycline resistance genes $\operatorname{otr}(\mathrm{A}), \operatorname{otr}(\mathrm{B})$, $\operatorname{tet}(\mathrm{K}), \operatorname{tet}(\mathrm{L}), \operatorname{tet}(\mathrm{M}), \operatorname{tet}(\mathrm{V})$ and $\operatorname{tap}$ was assessed with $\mathrm{PCR}$ using gene-specific primers (Table 1). The total volume of PCR reactions was $25 \mu \mathrm{L}$ and $1 \mu \mathrm{L}$ of mycobacterial lysates (see above) or $\sim 20$ 50 ng of chromozomal DNA from positive control strains or plasmid DNA were used as a template. The cycling conditions for each gene are shown in Table 1 .

The genes $\operatorname{otr}(\mathrm{A}), \operatorname{otr}(\mathrm{B})$ and $\operatorname{tap}$ were amplified with the help of Qiagen Taq polymerase and Q-solution (Qiagen, Hilden, Germany). The final reaction mixtures contained (final concentrations) Qiagen Taq buffer $(1 \times)$, Qiagen Q-solution $(1 \times)$, dNTPs (Fermentas, Thermo Fisher Scientific; $0.2 \mathrm{mM}$ each), primers [500 $\mathrm{nM}$ in the case of $\operatorname{otr}(\mathrm{A})$ and $\operatorname{tap}$, and $100 \mathrm{nM}$ in the case of $\operatorname{otr}(\mathrm{B})]$ and Qiagen Taq polymerase $\left(0.05 \mathrm{U}^{-1} \mathrm{~L}^{-1}\right)$. The genes $\operatorname{tet}(\mathrm{K})$ and (L) (co-amplified), tet $(\mathrm{V})$ and $\operatorname{tet}(\mathrm{M})$ were amplified using Dream Taq polymerase (Fermentas, Thermo Fisher Scientific) and the final reaction mixtures contained Dream Taq buffer [with $\left(\mathrm{NH}_{4}\right)_{2} \mathrm{SO}_{4}$, without $\left.\mathrm{MgCl}_{2} ; 1 \times\right], \mathrm{MgCl}_{2}(1.5 \mathrm{mM})$, dNTPs $(0.2 \mathrm{mM}$ each), primers (500 nM each), dimethyl sulfoxide (Sigma-Aldrich; 5\%), bovine serum albumin (Fermentas, $1.2 \mathrm{mg} \mathrm{mL}^{-1}$ ) and Dream Taq polymerase $\left(0.05 \mathrm{U} \mu \mathrm{L}^{-1}\right)$. Five microliters of PCR products were analyzed in 1-2\% agarose gel (Top Vision agarose, Fermentas, Thermo Fisher Scientific) stained with ethidium bromide (1 mg $\mathrm{L}^{-1}$ ), $30 \mathrm{~min}$, for the presence of bands of the expected size.

The specificity of primer pairs designed in this study, i.e., tetKLFW/tetKL-RV, and tetV-FW/tetV-RV was tested by PCR with other tetracycline efflux pump genes as a template (negative controls). The tetKL-FW/tetKL-RV were tested against plasmids containing genes $\operatorname{tet}(\mathrm{A}), \operatorname{tet}(\mathrm{B}), \operatorname{tet}(\mathrm{C}), \operatorname{tet}(\mathrm{D}), \operatorname{tet}(\mathrm{E}), \operatorname{tet}(\mathrm{G}), \operatorname{tet}(\mathrm{H}), \operatorname{tet}(\mathrm{J}), \operatorname{tet}(\mathrm{V})$, tet $(\mathrm{Y}), \operatorname{tet}(\mathrm{Z})$ and agaist Streptomyces rimosus subsp. rimosus DSMZ 40260 chromosomal DNA containing $\operatorname{otr}(\mathrm{B})$. Primers tetV-FW/tetV$\mathrm{RV}$ were tested against $\operatorname{tet}(\mathrm{A}), \operatorname{tet}(\mathrm{B}), \operatorname{tet}(\mathrm{C}), \operatorname{tet}(\mathrm{D}), \operatorname{tet}(\mathrm{E}), \operatorname{tet}(\mathrm{H})$, $\operatorname{tet}(\mathrm{J}), \operatorname{tet}(\mathrm{K}), \operatorname{tet}(\mathrm{L}), \operatorname{tet}(\mathrm{Y}), \operatorname{tet}(\mathrm{Z})$ and $\operatorname{otr}(\mathrm{B})(6,7)$.

Amplified tet $(\mathrm{V})$ or tap genes were cleaned-up with the GenElute PCR Clean-Up Kit (Sigma-Aldrich) and sequenced from both ends in the case of $\operatorname{tet}(\mathrm{V})$ and from the forward primer in the case of tap, as described above. The sequences were edited and assembled with Bioedit 7.0.4.1 software (23) and compared to the GenBank database (www.ncbi.nml.nih.gov) using blastn and blastp algorithms. Altogether, $46 \mathrm{PCR}$ products of $\operatorname{tet}(\mathrm{V})$ and $14 \mathrm{PCR}$ products of tap were sequenced.

\section{Phylogeny analyses of tet $(V)$}

Phylogeny analyses were conducted in MEGA software version 4.0 (http://www.megasoftware.net/) (46). The partial sequences of $\operatorname{tet}(\mathrm{V})$ (311 nucleotides) were aligned together with the published sequence of $M$. smegmatis tet $(\mathrm{V})$ (GenBank, gb|CP000480.1|: 5286339-5287598) and M. vanbaalenii $\mathrm{H}+$ antiporter gene (GenBank, CP000511.1). The neighbor-joining phylogenetic tree was constructed based on the nucleotide sequences using Kimura-2 parameter. The correlation between the distance matrices of tet $(\mathrm{V})$ sequences of 43 isolates and corresponding BOX-PCR profiles was assessed with the Mantel test in R (http://www.r-project.org/), ADE4 package (47), using 1,000 repetitions.

\section{Accession numbers}

The $\operatorname{tet}(\mathrm{V})$ sequences were deposited in GenBank under accession numbers JF290326-JF290351 and JQ348076-JQ348095, and the tap sequences under accession numbers JF290352-JF290365. The 16S rRNA gene sequences are available in GenBank under accession numbers JF304573-JF304610 and JQ348096-JQ348111.

\section{Results}

\section{Isolate identification and genome relatedness}

Forty-four isolates from grasslands and 38 clinical isolates were included in this study (Table S2, S3 and S4). The environmental isolates were divided into 14 distinct groups and the clinical isolates into 28 distinct groups according to their BOX-PCR profile similarity, using the Pearson correlation coefficient threshold of 0.7 (Table 2, 3 and Fig. S1). Clinical and environmental strains always belonged to separate BOX-PCR groups.

A minimum of one isolate from each environmental BOXPCR group was identified by sequencing the $16 \mathrm{~S}$ rRNA gene and comparing to the type strain database using EzTaxon $\mathrm{v}$ 2.1 software (Tables 2 and S2). Most of the soil isolates (i.e., 26) had sequences identical or almost identical (98-100\% pairwise sequence similarity) to the species Mycobacterium septicum, 2 isolates to Mycobacterium fortuitum subsp. acetamidolyticum, 1 isolate to Mycobacterium alvei, 1 isolate to Mycobacterium litorale and 1 isolate to Mycobacterium aubagnense. The isolates from one BOX-PCR group were usually assigned to the same species, with the exception of 
Table 2. Tetracycline resistance and presence of resistance genes in the environmental isolates

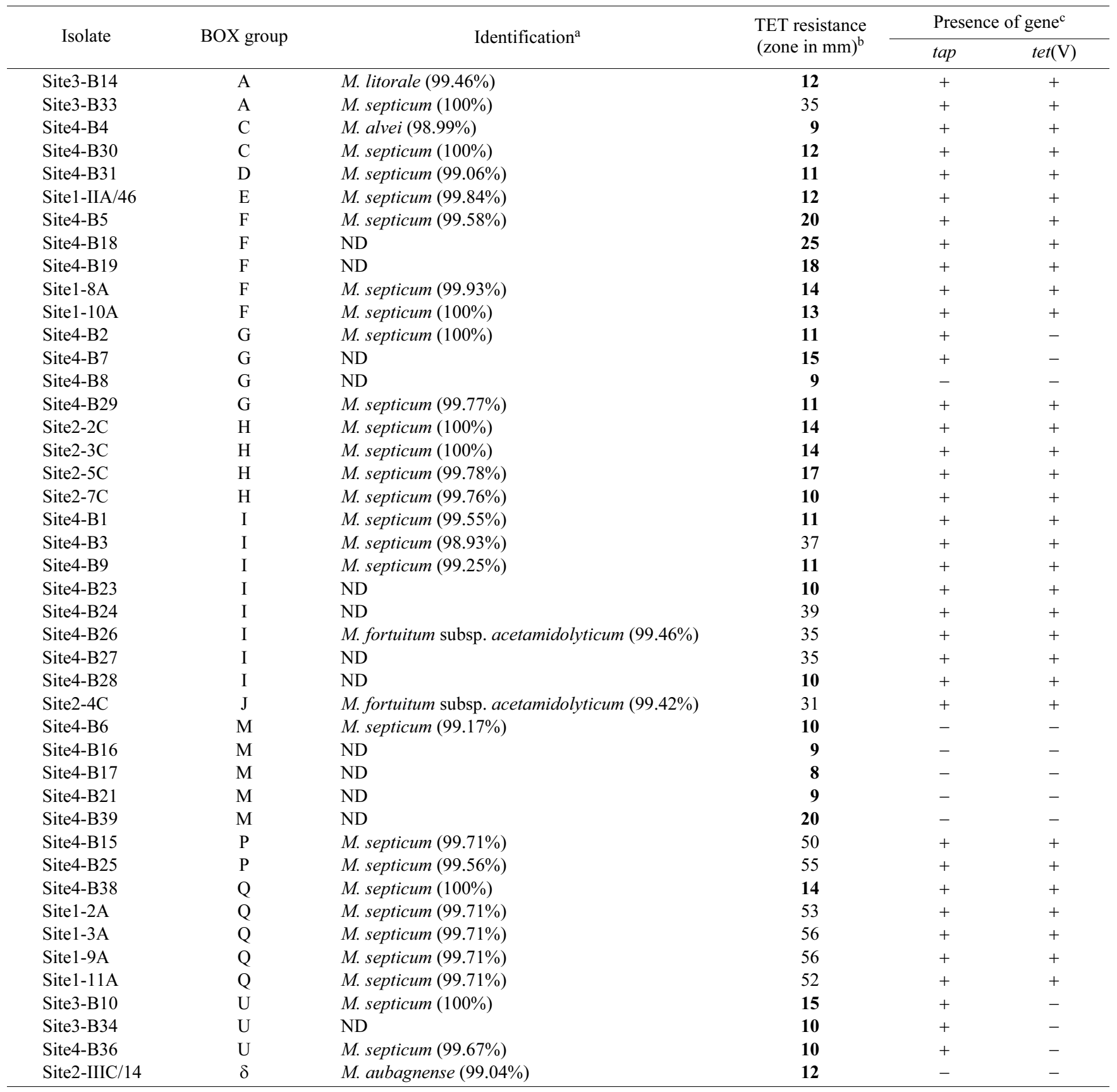

${ }^{a}$ In parentheses, \% pairwise sequence similarity with the closest type strain on EzTaxon is shown. ND, not done.

b Resistance in bold.

${ }^{c}$ The genes $\operatorname{otr}(\mathrm{A}), \operatorname{otr}(\mathrm{B}), \operatorname{tet}(\mathrm{K})(\mathrm{L})$ and $\operatorname{tet}(\mathrm{M})$ were detected in none of the isolates.

group A, where isolates were attributed either to M. septicum or to $M$. litorale, group $\mathrm{C}$ where one isolate was attributed to $M$. alvei and another to M. septicum, and group I (3 isolates attributed to $M$. septicum and one to $M$. fortuitum). The set of clinical isolates was more diverse and comprised 17 species, of which $M$. fortuitum was the most prevalent (29\%), followed by $M$. neoaurum (16\%) (Table 3 and S3). As in the case of the soil isolates, different species sometimes occurred in the same BOX-PCR group, e.g., M. septicum and $M$. fortuitum in group R, M. goodie and $M$. neoaurum in group $\mathrm{V}$, and M. abscessus and M. fortuitum in group $\lambda$.

\section{Resistance to tetracycline}

The distribution of TET resistance was bimodal in both clinical and environmental strains (Fig. 1). Since standard breakpoints of the disc diffusion method are not available for RGM, we arbitrarily set them according to the zone size distributions. An isolate was considered to be resistant if the zone was up to $25 \mathrm{~mm}$. Based on the arbitrary breakpoint, thirty-two environmental (70\%) and sixteen clinical isolates (53\%) were resistant to TET (Table 2 and 3). There was no significant difference in TET resistance (in terms of zone 
Table 3. Tetracycline resistance and presence of resistance genes in the clinical isolates

\begin{tabular}{|c|c|c|c|c|c|}
\hline \multirow{2}{*}{ Isolate } & \multirow{2}{*}{ BOX group } & \multirow{2}{*}{ Identification } & \multirow{2}{*}{$\begin{array}{l}\text { TET resistance } \\
\text { (zone in } \mathrm{mm} \text { ) }\end{array}$} & \multicolumn{2}{|c|}{ Presence of gene ${ }^{b}$} \\
\hline & & & & tap & $\operatorname{tet}(\mathrm{V})$ \\
\hline OS6 & $\mathrm{B}$ & M. novacastrense $(99.56 \%)$ & $60 *$ & + & - \\
\hline OS2/8 & $\mathrm{K}$ & M. peregrinum $^{\mathrm{a}}$ & 6.5 & + & + \\
\hline TR-1378 & $\mathrm{L}$ & M. fortuitum ${ }^{\mathrm{a}}$ & 17 & + & - \\
\hline $\mathrm{OS} 2 / 2$ & $\mathrm{~N}$ & M. arupense $(100 \%)$ & $6.5 *$ & - & - \\
\hline TR-1536 & $\mathrm{O}$ & M. franklinii $(100 \%)$ & 6.5 & - & - \\
\hline OS19 & $\mathrm{R}$ & M. septicum $(100 \%)$ & 6.5 & + & - \\
\hline OS2/7 & $\mathrm{R}$ & M. fortuitum ${ }^{\mathrm{a}}$ & 11 & + & - \\
\hline OS14 & $\mathrm{S}$ & M. septicum $(100 \%)$ & 11 & + & + \\
\hline OS16 & $\mathrm{T}$ & M. septicum $(100 \%)$ & 6.5 & + & - \\
\hline TR-1358 & $\mathrm{V}$ & M. goodii $(99.77 \%)$ & 41 & + & + \\
\hline OS2 & $\mathrm{V}$ & M. neoaurum $(99.37 \%)$ & 58 & + & - \\
\hline TR-1344 & W & M. llatzerense $(98.40 \%)$ & 11 & - & - \\
\hline TR-1380 & $\mathrm{X}$ & M. arupense $(98.95 \%)$ & 55 & - & + \\
\hline OS22 & $\mathrm{Y}$ & M. nеоаитит $(100 \%)$ & 48 & + & + \\
\hline OS29 & $\mathrm{Y}$ & M. neoaurum $(100 \%)$ & 54 & + & - \\
\hline OS2/1 & $\mathrm{Z}$ & M. nonchromogenicum $(98.91 \%)$ & $6.5 *$ & - & - \\
\hline TR-1294 & $\alpha$ & M. neoaurum $(99.76 \%)$ & 47 & + & - \\
\hline OS3 & $\alpha$ & M. neoaurum $(100 \%)$ & 48 & + & - \\
\hline OS8 & $\beta$ & M. fortuitum ${ }^{\mathrm{a}}$ & 9 & + & + \\
\hline OS26 & $\gamma$ & M. neoaurum $(100 \%)$ & 57 & + & - \\
\hline OS27 & $\varepsilon$ & M. obuense $(99.78 \%)$ & 48 & + & - \\
\hline OS4 & $\zeta$ & M. rufum $(100 \%)$ & 52 & + & - \\
\hline TR-1359 & $\eta$ & M. rufum $(99.76 \%)$ & 61 & + & - \\
\hline OS13 & $\theta$ & M. abscessus ${ }^{\mathrm{a}}$ & 9 & - & - \\
\hline TR-1242 & 1 & M. fortuitum subsp. fortuitum (99.88\%) & 52 & + & + \\
\hline TR-1266 & 1 & M. fortuitum subsp. fortuitum (100\%) & 6.5 & + & + \\
\hline OS24 & 1 & M. fortuitum ${ }^{\mathrm{a}}$ & 6.5 & + & + \\
\hline OS25 & 1 & M. fortuitum ${ }^{\mathrm{a}}$ & 6.5 & + & + \\
\hline OS9 & $\kappa$ & M. fortuitum ${ }^{\mathrm{a}}$ & 6.5 & + & + \\
\hline OS28 & $\kappa$ & M. fortuitum ${ }^{\mathrm{a}}$ & 55 & + & + \\
\hline OS10 & $\lambda$ & M. abscessus ${ }^{\mathrm{a}}$ & 6.5 & - & - \\
\hline OS30 & $\lambda$ & M. fortuitum ${ }^{\mathrm{a}}$ & 6.5 & + & + \\
\hline OS21 & $\mu$ & M. fortuitum ${ }^{\mathrm{a}}$ & 31 & + & + \\
\hline OS18 & $v$ & M. hiberniae $(99.78 \%)$ & $6.5 *$ & - & - \\
\hline $\mathrm{OS} 2 / 4$ & $v$ & M. hiberniae $(99.78 \%)$ & $6.5^{*}$ & - & - \\
\hline OS11 & $\xi$ & M. mucogenicum ${ }^{\mathrm{a}}$ & 49 & + & - \\
\hline OS7 & $\pi$ & M. frederiksbergense $(99.56 \%)$ & 55 & + & - \\
\hline OS1 & $\rho$ & M. smegmatis ${ }^{\mathrm{a}}$ & 38 & - & - \\
\hline
\end{tabular}

a Identified with the GenoType Mycobacterium CM (Common Mycobacteria) Test based on DNA Strip technology (Hain Lifescience)

${ }^{b}$ The genes $\operatorname{otr}(\mathrm{A}), \operatorname{otr}(\mathrm{B}), \operatorname{tet}(\mathrm{K})(\mathrm{L})$ and $\operatorname{tet}(\mathrm{M})$ were detected in none of the isolates.

* Measured on Šula's medium (43).

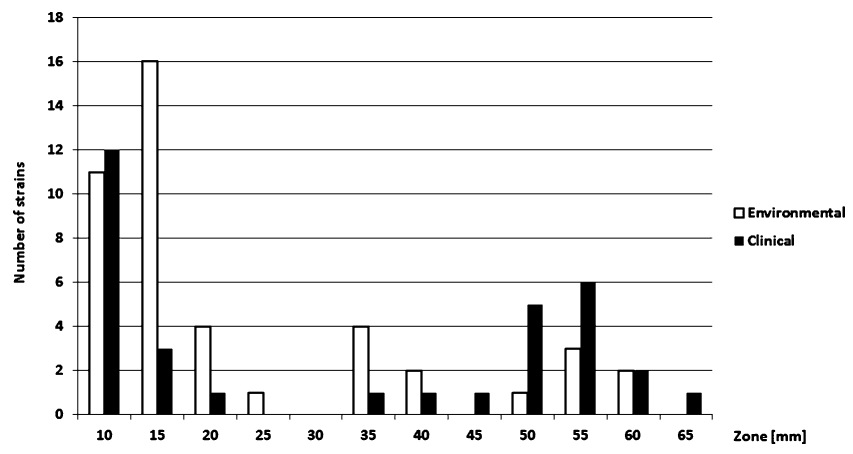

Fig. 1. Tetracycline resistance in the clinical and the environmental isolates of rapidly growing mycobacteria. Bars represent the number of isolates with the corresponding inhibition zone size around $30 \mu \mathrm{g}$ tetracycline disks. sizes, assessed with Wilcoxon rank sum test) between the environmental and clinical isolates. Tetracycline resistance was not a specific characteristic of individual BOX-PCR groups, i.e., both resistant and sensitive isolates could be found within the same BOX-PCR group.

\section{Detection of tetracycline resistance genes}

The two primer pairs designed in this study, i.e., tetV-FW/ tetV-RV [tet(V) detection], and tetKL-FW/tetKL-RV [simultaneous detection of $\operatorname{tet}(\mathrm{K})$ and $\operatorname{tet}(\mathrm{L})]$, were tested for their specificity in PCR using different tetracycline efflux pump genes as templates. Both primer pairs were specific, i.e., they amplified only $\operatorname{tet}(\mathrm{V})$ in the case of tetV-FW/tetV-RV and $\operatorname{tet}(\mathrm{K})$ and $\operatorname{tet}(\mathrm{L})$ in the case of tetKL-FW/tetKL-RV (data not shown). The specificity of the tetV-FW/tetV-RV primer 
pair was further corroborated by sequencing the PCR products (see below).

All isolates were tested for the presence of $\operatorname{otr}(\mathrm{A}), \operatorname{otr}(\mathrm{B})$, $\operatorname{tet}(\mathrm{K}) / \operatorname{tet}(\mathrm{L}), \operatorname{tet}(\mathrm{M}), \operatorname{tet}(\mathrm{V})$ and tap. The gene $\operatorname{tet}(\mathrm{V})$ was detected in 32 of the total 44 environmental strains (73\%) and in fourteen clinical isolates (37\%) (Table 2 and 3). The environmental isolates harboring $\operatorname{tet}(\mathrm{V})$ were assigned to the species $M$. septicum, M. litorale, M. alvei and M. fortuitum. The clinical isolates with $\operatorname{tet}(\mathrm{V})$ belonged to the species $M$. fortuitum, M. peregrinum, $M$. septicum, M. goodii, $M$. arupense and $M$. neoaurum. Surprisingly, $\operatorname{tet}(\mathrm{V})$ was found also in isolates that were sensitive to tetracycline (even in those with zones over $50 \mathrm{~mm}$ ) (Table 2 and 3). The gene tap was detected in 37 environmental isolates $(84 \%)$ and in 28 clinical isolates (74\%). The environmental isolates with tap belonged to the species $M$. fortuitum, M. alvei, M. septicum, and the clinical isolates to the species $M$. fortuitum, $M$. novacastrense, $M$. peregrinum, M. septicum, M. goodi, $M$. neoaurum, M. rufum, M. obuense, $M$. frederiksbergense and M. mucogenicum. Similarly to tet(V), tap was detected also in strains that were sensitive to tetracycline. In contrast, the genes $\operatorname{otr}(\mathrm{A}), \operatorname{otr}(\mathrm{B}), \operatorname{tet}(\mathrm{K}) / \operatorname{tet}(\mathrm{L})$ and $\operatorname{tet}(\mathrm{M})$ were not detected in any isolate, and eight clinical and seven environmental isolates were resistant to TET but possessed none of the tested genes.

\section{Analyses of tet $(V)$ and tap sequences}

The gene tet $(\mathrm{V})$ was sequenced in all isolates (i.e., 46) where we obtained positive signals from PCR. Sequences of isolates Site2-3C, Site2-5C and Site2-7C (all from the BOXPCR group $\mathrm{H}$ ) were not used for further analyses since they contained several ambiguous peaks that could not be resolved (although PCR and sequencing were attempted twice). It is possible that these isolates had two copies of $\operatorname{tet}(\mathrm{V})$ that differed slightly in their sequences.

The 43 analyzed partial sequences of the gene $\operatorname{tet}(\mathrm{V})$ [corresponding to positions 823-1,132 of M. smegmatis MC2-155 tet $(\mathrm{V})]$ differed substantially among the isolates, with $17 \%$ differences between two most distant isolates (Fig. 2 ). The isolates shared $82-88 \%$ and $90-95 \%$ identity, respectively, of nucleic and inferred amino acid sequences with the published tet $(\mathrm{V})$ sequence of $M$. smegmatis MC2155. Since all the recovered sequences had amino acid identity above $80 \%$ with the published $\operatorname{tet}(\mathrm{V})$, they can be attributed to the tet $(\mathrm{V})$ gene class (32). Interestingly, M. neoarum OS22 had a one-nucleotide deletion at position 915. The phylogeny of $\operatorname{tet}(\mathrm{V})$ (Fig. 2) shared overall similarity with the genome relatedness of the strains (Fig. 3), and the soil isolates usually clustered separately from clinical RGM. Indeed, there was a significant correlation $(r=0.64, P=0.001)$ between the BOXPCR profile- and tet $(\mathrm{V})$ sequence-based distant matrices.

Fourteen PCR products of tap (corresponding to positions 764-1,080 of tap M. fortuitum) (4) were chosen for sequencing in order to verify the specificity of primers and check for tap gene diversity. Similarly to tet $(\mathrm{V})$, differences in the partial sequences of tap between our isolates and the published sequence were found (data not shown). Out of the sequenced isolates, M. fortuitum subsp. fortuitum TR-1242 had the tap sequence most similar to the published sequence (99\% identity), while the M. rufum TR-1359 tap sequence

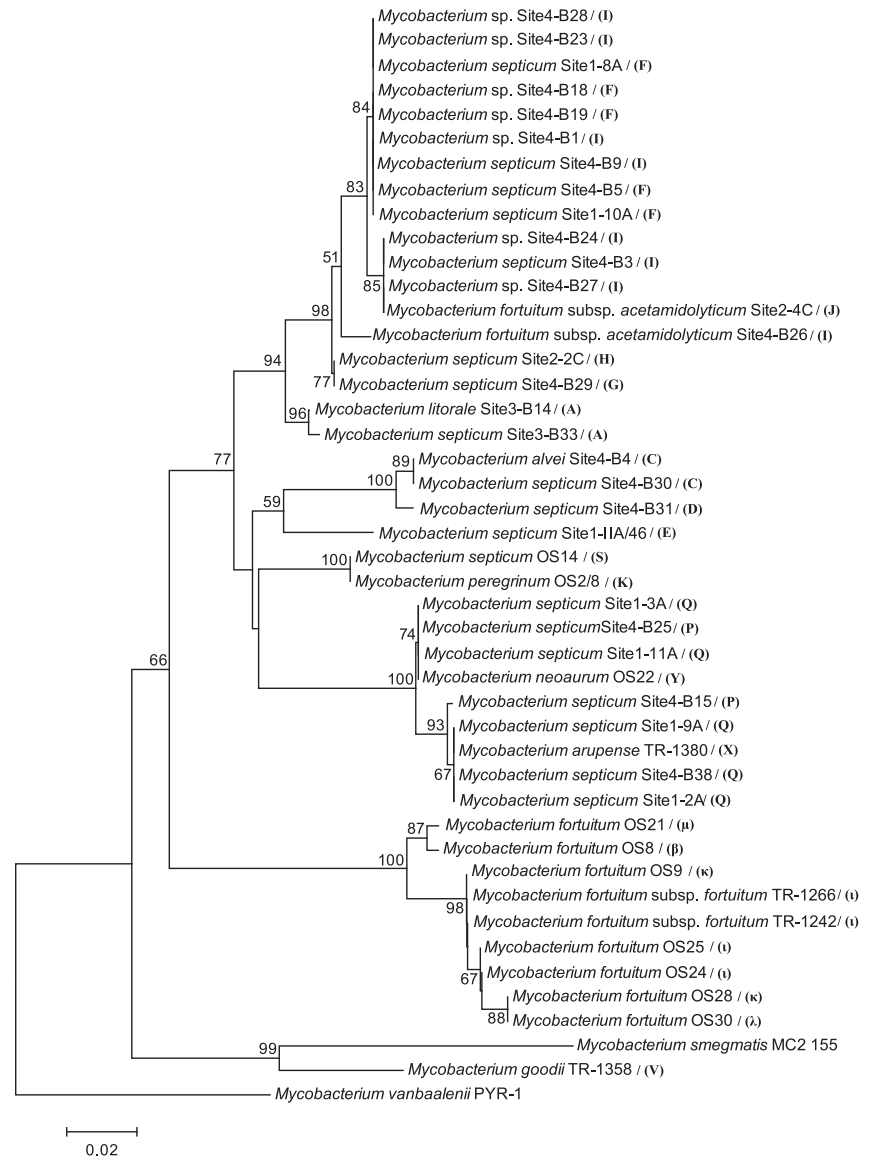

Fig. 2. Phylogenetic tree based on the nucleotide sequences of tet $(\mathrm{V})$, constructed by the neighbor-joining method using Kimura-2 parameter. Bootstrap values are indicated at the nodes as a percentage of 1,000 replications, if they were higher than $50 \%$. Letters following the isolate names indicate the BOX-PCR groups the isolates belonged to.

was the most dissimilar (only 79\% identity). The environmental isolates had $82-89 \%$ sequence identity with the published tap sequence, and there was quite a high diversity of the sequences among the environmental isolates (up to $15 \%$ substitutions). The number of differences was lower at the amino acid level (96-100\% amino acid identities).

\section{Discussion}

In general, the distribution of TET resistance did not differ between the soil and the clinical RGM and the same TETresistance genes were found in both groups. The gene $\operatorname{tet}(\mathrm{V})$ encoding a tetracycline efflux pump (19) was found in $73 \%$ soil isolates and $37 \%$ clinical isolates, including species where it has not been reported previously, i.e., M. septicum, $M$. litorale, M. alvei, M. peregrinum, M. goodii, M. arupense and $M$. neoaurum. This study also showed the high diversity of $\operatorname{tet}(\mathrm{V})$ (up to $17 \%$ difference between two sequences), which is unusual among other tet gene classes. For example, the published sequences of tet(B), a horizontally transferred TET efflux pump with at least 20 reported host genera (40), did not differ from each other in more than $1 \%$ nucleotides (analysis not shown). This finding, together with the positive correlation between the BOX-PCR profiles and $\operatorname{tet}(\mathrm{V})$ phylogeny, suggest that $\operatorname{tet}(\mathrm{V})$ evolved together with the 

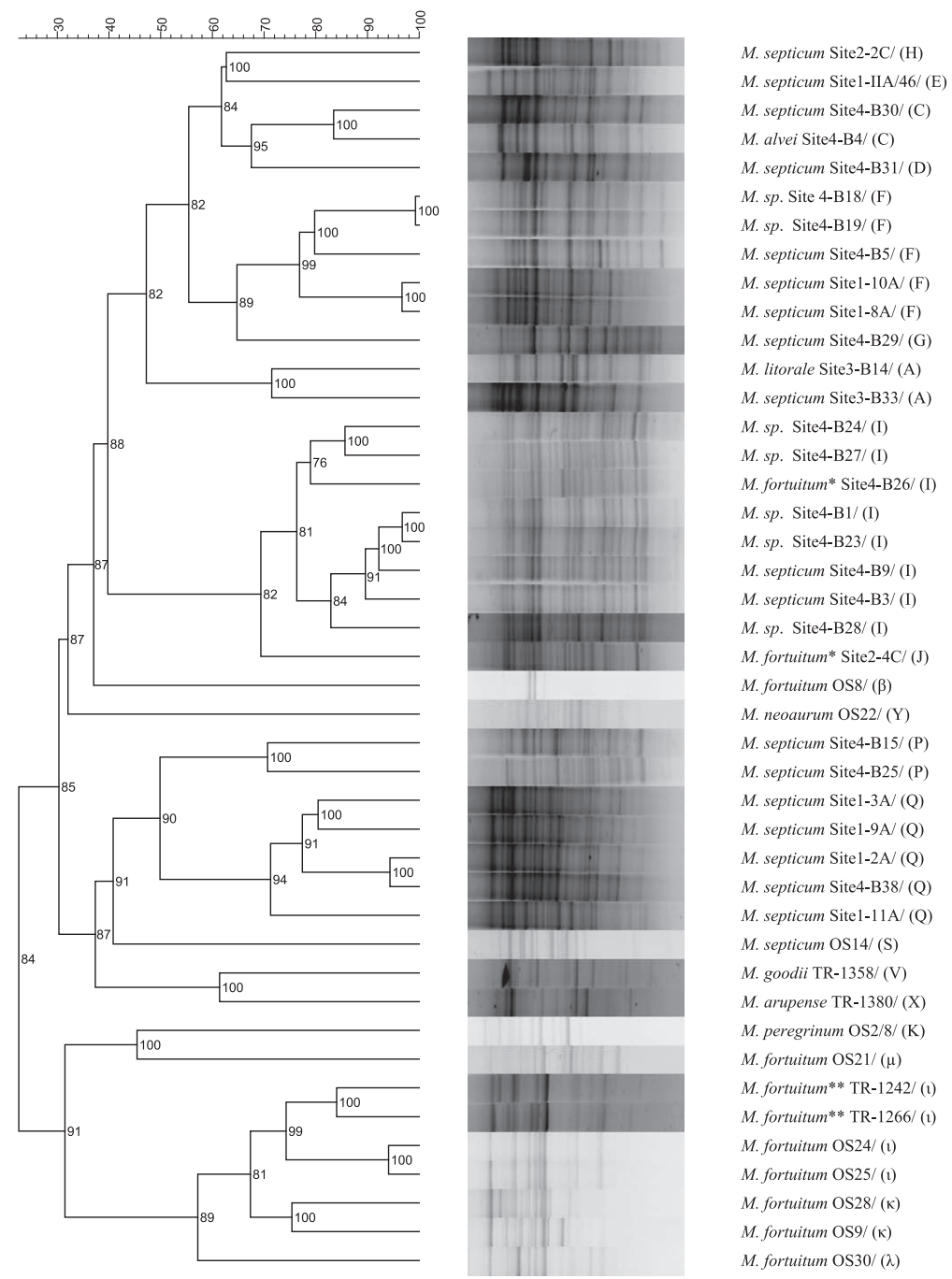

Fig. 3. BOX-PCR profiles of $43 \mathrm{RGM}$ isolates with sequenced $\operatorname{tet}(\mathrm{V})$. Left, UPGMA-clustering of the isolates based on the similarity matrix of their BOX-PCR profiles. Right, isolate names preceded by a letter indicating the BOX-PCR groups (based on the $\geq 70 \%$ similarity threshold). See Fig. S1 for BOX-PCR profiles of all isolates from this study.

mycobacterial genomes rather than being acquired horizontally. These findings therefore support the hypothesis that $\operatorname{tet}(\mathrm{V})$ belongs to the mycobacterium intrinsic resistome; however, in certain cases, different RGM species (e.g., $M$. arupense and $M$. septicum) shared the same partial tet(V) sequence, so the horizontal exchange of $\operatorname{tet}(\mathrm{V})$ among mycobacteria cannot be completely excluded. It is also conceivable that this gene underwent a long evolution within a certain group of RGM species from which it was horizontally transferred to other RGM species later. Comparative studies of the tet $(\mathrm{V})$ gene and its sourroundings in a broader set of RGM species might be the next step to learn more about antibiotic resistance evolution in mycobacteria.

BLAST search revealed the presence of tet $(\mathrm{V})$ homologues in the sequenced genomes of seven mycobacterial strains and in seven other actinomycetes; for example, there was a gene for $\mathrm{H}+$ antiporter of $M$. vanbaalenii PYR-1 (86\% identity), Mycobacterium sp. JLS (CP000580.1, 82\% identity), Mycobacterium sp. KMS (CP000518.1, 82\% identity) or major facilitator superfamily protein of Geodermatophilus obscurus DSM 43160 (CP001867.1, 73\% identity). These genes may potentially code for drug resistance and therefore merit further attention. It is also possible that tet $(\mathrm{V})$ is present in more mycobacterial species but has not been detected with PCR because of its high diversity and thus possible lack of complementarity with the primers used here.

The gene tap, which confers low-level resistance to tetracycline and certain aminoglycosides (4), seems to be very common among RGM. In our study, we found it in $84 \%$ environmental and $74 \%$ clinical isolates. Likewise, Esteban et al. (22) found tap in most (66\%) of the clinical RGM tested. Besides the species in which tap has already been reported (22), it was detected also in M. litorale, $M$. novacastrense, $M$. septicum, M. goodi, M. neoaurum, $M$. rufum, $M$. obuense, $M$. frederiksbergense and $M$. mucogenicum. Based on the number of identities with the published tap sequence, it seems that we recovered more diverse tap sequences (83-99\% identity) than Esteban et al. (22) (92-95\% identity), using the same primers. Analysis of more sequences would be necessary to show whether there is a correlation between BOX-PCR profiles and tap phylogeny, as in the case of $\operatorname{tet}(\mathrm{V})$. 
Surprisingly, tet(V) and/or tap were found also in the isolates that were highly susceptible to TET. Although our sequences of Tet(V) differed from that for which functionality was previously shown (19), there was no correlation between the $\operatorname{tet}(\mathrm{V})$ alleles and TET inhibition zone size; for example, two clinical $M$. fortuitum had the same sequence (at least in the part analyzed) but markedly differed in resistance. In general, sense mutations prevailed over the mutations changing the amino acid sequence, indicating that the function was rather to be maintained; however, M. neoaurum OS22 had one nucleotide deletion in the analyzed part of $\operatorname{tet}(\mathrm{V})$ that would change the reading frame, and this isolate was sensitive to tetracycline. It is possible that point deletions in the unanalyzed parts of the tet $(\mathrm{V})$ sequence occurred also in other isolates. In addition, the observed discrepancy between genotype and phenotype may be due to mutations in distant regulation regions or to gene expression regulation; for example, Nash et al. (35) noticed that high clarithromycin resistance was inducible by overnight incubation of certain sensitive mycobacteria with a low concentration of the antibiotic. The discrepancy between the presence of a resistance gene and the resistance to TET in RGM or other bacteria was reported previously $(5,22)$. TET-resistant isolates in which tet $(\mathrm{V})$ and tap were not detected could either differ in their tet $(\mathrm{V})$ and tap sequences from the used primers or possess other TET resistance genes that were not tested. The search for horizontally transferred TET resistance genes so far described in RGM was unsuccessful, though it included the genes $\operatorname{tet}(\mathrm{M})$ and $\operatorname{tet}(\mathrm{L})$, which are commonly found in Gram-positive bacteria in manure $(1,3)$. The number of studies reporting horizontally transferred TET resistance genes in $\operatorname{RGM}$ is low $(38,41)$ and it could be that there are marked local differences in the distribution of these genes in RGM.

The majority of the soil as well as clinical isolates from this study belonged to the Mycobacterium fortuitum group. Most soil isolates had the highest 16S rRNA sequence similarity to the species $M$. peregrinum, M. septicum or $M$. fortuitum, which all include potential human pathogens (29, 48). Some of the isolates close to M. septicum indeed grew at $37^{\circ} \mathrm{C}$ (data not shown), indicating they may be able to colonize the human body; however, the soil and clinical isolates of M. septicum from this study were genetically different, as shown by analyses of their BOX-PCR profiles (and the same applies also to $M$. fortuitum isolates). The species in the $M$. fortuitum group are frequently recovered from soil (25), including agricultural soils $(20,53)$, as well as from clinical samples $(24,50)$, but so far a direct relationship between a clinical manifestation and exposure to soil has not been clearly shown in this group. The group M. chelonae-M. abscessus was reported as being even more frequent than the M. fortuitum group in clinical samples (24, 50 ), but not in our case. The discrepancy between BOX-PCR groups and the assignment of isolates to species (e.g., $\mathrm{BOX}$ PCR groups A, C or I) can be because the BOX-PCR groups were defined quite broadly (70\% similarity) (12), but it can also indicate the need for more comprehensive taxonomical evaluation of RGM, as already shown in the case of streptomycetes (31).

In this study, we tested resistance to tetracycline and not to clinically used doxycycline, which was relevant in the context of soil since tetracycline residues are found in soil and manure (10). Ultimately, the zone sizes with tetracycline and doxycycline disks were correlated (tested with 32 isolates, Pearson correlation $0.88, P<0.01$, data not shown). It was previously shown with the disk dilution method that RGM susceptible to tetracycline were also susceptible to doxycline, although the MIC values were 1-2 dilutions lower for doxycycline (52). Interestingly, there was no difference in the zone size distribution between clinical and environmental RGM and more than half of the isolates from both groups were resistant to tetracycline. The bimodal distribution of resistance to tetracycline antibiotics was reported previously $(44,52)$. Both resistant and sensitive phenotypes occurred within one species (e.g., within M. fortuitum or within $M$. septicum), and even within one BOX-PCR group (Table 2 and 3). We thus did not observe any consistency between BOX-PCR fingerprints and antibiotic resistance phenotypes, in contrast to Davelos Baines et al. (13), who found significant correlations between antibiotic phenotypes and BOX-PCR fingerprints in soil streptomycetes. This could be because the selection pressure for antibiotic resistance in soil acts on a much smaller scale than we sampled (13) and because antibiotic resistance in individual mycobacterial isolates can be affected by point mutations that would not significantly affect their BOX-PCR profiles. The variable resistance to tetracycline antibiotics within the $M$. fortuitum group is consistent with previous studies, usually reporting 40-60\% sensitive isolates $(24,44,52)$.

\section{Conclusion}

In conclusion, the studied soil and the clinical RGM from the Czech Republic did not differ in the distribution of TET resistance and occurrence of TET resistance genes, most possessing efflux-pump encoding genes tet(V) and/or tap. This study shows for the first time the presence of $\operatorname{tet}(\mathrm{V})$ and tap in soil mycobacteria. The correlation between the tet $(\mathrm{V})$ phylogeny and isolate genomic profiles indicates that $\operatorname{tet}(\mathrm{V})$ belongs to the mycobacterial intrinsic resistom. The intrinsic efflux pumps may therefore play an important role in the antibiotic resistance of RGM, as in the case of $M$. tuberculosis $(18,33)$. The simple presence of efflux-pump encoding genes, however, did not always match TET resistance. Further research should therefore be performed on gene diversity, distribution and expression in order to better understand the mycobacterial intrinsic resistom.

\section{Acknowledgements}

This work was funded by the Grant Academy of the Czech Republic, project P504/10/2077, Ministry of Education, Youth and Sport of the Czech Republic, project LC06066. We are grateful to F. M. Aarestrup, National Food Institute, Technical University of Denmark, Copenhagen, and H. Schmitt, Institute for Risk Assessment Sciences (IRAS), Utrecht University (with the permission of R. Aminov, Rowett Institute of Nutrition and Health, University of Aberdeen) for the gift of strains. We thank $Z$. Stehlíková, (Biology Center AS CR, v.v.i., Institute of Soil Biology, Czech Republic) for technical help. GENERI BIOTECH, s.r.o., and the Laboratory of Genomics (Biology Centre AS CR, v.v.i., Institute of Plant Molecular Biology) are acknowledged for sequencing. 


\section{References}

1. Aarestrup, F.M., Y. Agerso, P. Gerner-Smidt, M. Madsen, and L.B. Jensen. 2000. Comparison of antimicrobial resistance phenotypes and resistance genes in Enterococcus faecalis and Enterococcus faecium from humans in the community, broilers, and pigs in Denmark. Diagn. Microbiol. Infect. Dis. 37:127-137.

2. Adékambi, T., A. Stein, J. Carvajal, D. Raoult, and M. Drancourt. 2006. Description of Mycobacterium conceptionense sp. nov., a Mycobacterium fortuitum group organism isolated from a posttraumatic osteitis inflammation. J. Clin. Microbiol. 44:12681273.

3. Agersø, Y., L.B. Jensen, M. Givskov, and M.C. Roberts. 2002. The identification of a tetracycline resistance gene tetM., on a Tn916-like transposon, in the Bacillus cereus group. FEMS Microbiol. Lett. 214:251-256

4. Aínsa, J.A., M.C. Blokpoel, I. Otal, D.B. Young, K.A. De Smet, and C. Martín. 1998. Molecular cloning and characterization of Tap, a putative multidrug efflux pump present in Mycobacterium fortuitum and Mycobacterium tuberculosis. J. Bacteriol. 180:5836-5843.

5. Alexander, T.W., T. Reuter, R. Sharma, L.J. Yanke, E. Topp, and T.A. McAllister. 2009. Longitudinal characterization of resistan Escherichia coli in fecal deposits from cattle fed subtherapeutic levels of antimicrobials. Appl. Environ. Microbiol. 75:7125-7134.

6. Aminov, R.I., N. Garrigues-Jeanjean, and R.I. Mackie. 2001. Molecular ecology of tetracycline resistance: development and validation of primers for detection of tetracycline resistance genes encoding ribosomal protection proteins. Appl. Environ. Microbiol. $67: 22-32$

7. Aminov, R.I., J.C. Chee-Sanford, N. Garrigues, B. Teferedegne, I.J. Krapac, B.A. White, and R.I. Mackie. 2002. Development, validation, and application of PCR primers for detection of tetracycline efflux genes of Gram-negative bacteria. Appl. Environ. Microbiol. 68:17861793.

8. Appelgren, P., F. Farnebo, L. Dotevall, M. Studahl, B. Jönsson, and B. Petrini. 2008. Late-onset posttraumatic skin and soft-tissue infections caused by rapid-growing mycobacteria in tsunami survivors. Clin. Infect. Dis. 47:e11-6.

9. Butler, M.J., E.J. Friend, I.S. Hunter, F.S. Kaczmarek, D.A. Sugden, and M. Warren. 1989. Molecular cloning of resistance genes and architecture of a linked gene cluster involved in biosynthesis of oxytetracycline by Streptomyces rimosus. Mol. Gen. Genet. 215:231238.

10. Chee-Sanford, J.C., R.I. Mackie, S. Koike, I.G. Krapac, Y.-F. Lin, A.C. Yannarell, S. Maxwell, and R.I. Aminov. 2009. Fate and transport of antibiotic residues and antibiotic resistance genes following land application of manure waste. J. Environ. Qual. 38:1086-1108

11. Chun, J., J.-H. Lee, Y. Jung, M. Kim, S. Kim, B.K. Kim, and Y.W. Lim. 2007. EzTaxon: a web-based tool for the identification of prokaryotes based on $16 \mathrm{~S}$ ribosomal RNA gene sequences. Int. J. Syst. Evol. Microbiol. 57:2259-2261.

12. Coenye, T., T. Spilker, A. Martin, and J.J. LiPuma. 2002. Comparative assessment of genotyping methods for epidemiologic study of Burkholderia cepacia genomovar III. J. Clin. Microbiol. 40:33003307.

13. Davelos Baines, A.L., K. Xiao, and L.L. Kinkel. 2007. Lack of correspondence between genetic and phenotypic groups amongst soil-borne streptomycetes. FEMS Microbiol. Ecol. 59:564-575.

14. D'Costa, V.M., K.M. McGrann, D.W. Hughes, and G.D. Wright. 2006. Sampling the antibiotic resistome. Science 311:374-377.

15. De Groote, M.A., and G. Huitt. 2006. Infections due to rapidly growing mycobacteria. Clin. Infect. Dis. 42:1756-1763.

16. De Groote, M.A., N.R. Pace, K. Fulton, and J.O. Falkinham III. 2006. Relationships between Mycobacterium isolates from patients with pulmonary mycobacterial infection and potting soils. Appl. Environ. Microbiol. 72:7602-7606

17. De Rossi, E., J.A. Aínsa, and G. Riccardi. 2005. Role of mycobacterial efflux transporters in drug resistance: an unresolved question. FEMS Microbiol. Rev. 30:36-52.

18. De Rossi, E., P. Arrigo, M. Bellinzoni, P.E.A. Silva, C. Martín, J.A Aínsa, P. Guglierame, and G. Riccardi. 2002. The multidrug transporters belonging to major facilitator superfamily (MFS) in Mycobacterium tuberculosis. Mol. Med. 8:714-724.
19. De Rossi, E., M.C.J. Blokpoel, R. Cantoni, M. Branzoni, G. Riccardi, D.B. Young, K.A.L. De Smet, and O. Ciferri. 1998. Molecular cloning and functional analysis of a novel tetracycline resistance determinant, tet $(\mathrm{V})$, from Mycobacterium smegmatis. Antimicrob. Agents Chemother. 42:1931-1937.

20. Donoghue, H.D., E. Overend, and J.L. Stanford. 1997. A longitudinal study of environmental mycobacteria on a farm in south-west England. J. Appl. Microbiol. 82:57-67.

21. Edwards, U., T. Rogall, H. Blöcker, M. Emde, and E.C. Böttger. 1989. Isolation and direct complete nucleotide determination of entire genes. Characterization of a gene coding for $16 \mathrm{~S}$ ribosomal RNA. Nucleic Acids Res. 17:7843-7853.

22. Esteban, J., N.Z. Martín-de-Hijas, A. Ortiz, T.J. Kinnari, A. Bodas Sánchez, I. Gadea, and R. Fernández-Roblas. 2009. Detection of lfrA and tap efflux pump genes among clinical isolates of non-pigmented rapidly growing mycobacteria. Int. J. Antimicrob. Agents 34:454456

23. Hall, T.A. 1999. BioEdit: a user-friendly biological sequence alignment editor and analysis program for Windows 95/98/NT. Nucleic Acids Symp. Ser. 41:95-98.

24. Han, X.Y., I. Dé, and K.L. Jacobson. 2007. Rapidly growing mycobacteria: clinical and microbiologic studies of 115 cases. Am. J. Clin. Pathol. 128:612-621.

25. Hartmans, S., J.A.M. De Bont, and E. Stackebrandt. 2006. The genus Mycobacterium-nonmedical, p. 889-918. In S. Falkow, E Rosenberg, K.-H. Schleifer, E. Stackebrandt, and M. Dworkin (ed.), The Prokaryotes, vol. 3. Springer-Verlag, New York.

26. Hindler, J.F., and S. Munro. 2010. Disk diffusion test, p. 5.1.1.5.1.13. In L.S. Garcia, and H.D. Isenberg (ed.), Clinical Microbiology Procedures Handbook, 3rd ed., vol. 2. ASM Press, Washington, DC.

27. Iivanainen, E. 1995. Isolation of mycobacteria from acidic forest soil samples: comparison of culture methods. J. Appl. Bacteriol. 78:663668.

28. Jirout, J., J. Tř́íska, K. Růžičková, and D. Elhottová. 2009. Disturbing impact of outdoor cattle husbandry on community of arbuscular mycorrhizal fungi in upland pasture soil. Commun. Soil Sci. Plant Anal. 40:736-745.

29. Lamy, B., H. Marchandin, K. Hamitouche, and F. Laurent. 2008 Mycobacterium setense sp. nov., a Mycobacterium fortuitum-group organism isolated from a patient with soft tissue infection and osteitis. Int. J. Syst. Evol. Microbiol. 58:486-490.

30. Lane, D.J., B. Pace, G.J. Olsen, D.A. Stahl, and N.R. Pace. 1985 Rapid determination of $16 \mathrm{~S}$ ribosomal RNA sequences for phylogenetic analyses. Proc. Nat. Acad. Sci. U.S.A. 82:6955-6959.

31. Lanoot, B., M. Vancanneyt, P. Dawyndt, M.C. Cnockaert, J Zhang, Y. Huang, Z. Liu, and J. Swings. 2004. BOX-PCR fingerprinting as a powerful tool to reveal synonymous names in the genus Streptomyces. Emended descriptions are proposed for the species Streptomyces cinereorectus, $S$. fradiae, S. tricolor, S. colombiensis, S. filamentous, S. vinaceus and S. phaeopurpureus. Syst. Appl. Microbiol. 27:84-92.

32. Levy, S.B., L.M. McMurry, T.M. Barbosa, V. Burdett, P. Courvalin, W. Hillen, M.C. Roberts, J.I. Rood, and D.E. Taylor. 1999. Nomenclature for new tetracycline resistance determinants. Antimicrob. Agents Chemother. 43:1523-1524.

33. Louw, G.E., R.M. Warren, N.C. Gey van Pittius, C.R.E. McEvoy, P.D. Van Helden, and T.C. Victor. 2009. A balancing act: efflux/ influx in mycobacterial drug resistance. Antimicrob. Agents Chemother. 53:3181-3189.

34. Martin, P., P. Trieu-Cuot, and P. Courvalin. 1986. Nucleotide sequence of the tet $M$ tetracycline resistance determinant of the streptococcal conjugative shuttle transposon Tn1545. Nucleic Acids Res. 14:7047-7058.

35. Nash, K.A., N. Andini, Y. Zhang, B.A. Brown-Elliott, and R.J. Wallace Jr. 2006. Intrinsic macrolide resistance in rapidly growing mycobacteria. Antimicrob. Agents Chemother. 50:3476-3478.

36. Nguyen, L., and C.J. Thompson. 2006. Foundations of antibiotic resistance in bacterial physiology: the mycobacterial paradigm. Trends Microbiol. 14:304-312.

37. Nikolakopoulou, T.L., S. Egan, L.S. van Overbeek, et al. 2005. PCR detection of oxytetracycline resistance genes $\operatorname{otr}(\mathrm{A})$ and $\operatorname{otr}(\mathrm{B})$ in tetracycline-resistant streptomycete isolates from diverse habitats. Curr. Microbiol. 51:211-216. 
38. Pang, Y., B.A. Brown, V.A. Steingrube, R.J. Wallace Jr, and M.C. Roberts. 1994. Tetracycline resistance determinants in Mycobacterium and Streptomyces species. Antimicrob. Agents Chemother. 38:1408-1412.

39. Redemaker, J.L.W., B. Hoste, F.J. Louws, K. Kersters, J. Swings, L. Vauterin, P. Vauterin, and J.F. van Bruijn. 2000. Comparison of AFLP and rep-PCR genomic fingerprinting with DNA-DNA homology studies: Xanthomonas as a model system. Int. J. Syst. Evol. Microbiol. 50:665-677.

40. Roberts, M.C. 2005. Update on acquired tetracycline resistance genes. FEMS Microbiol. Lett. 245:195-203.

41. Rossi-Fedele, G., W. Scott, D. Spratt, K. Gulabivala, and A.P. Roberts. 2006. Incidence and behaviour of Tn916-like elements within tetracycline-resistant bacteria isolated from root canals. Oral Microbiol. Immunol. 21:218-222.

42. Shirling, E.B., and D. Gottlieb. 1966. Methods for characterization of Streptomyces species. Int. J. Syst. Bacteriol. 16:313-340.

43. Sula, L. 1963. WHO co-operative studies on a simple culture technique for the isolation of mycobacteria. 1. Preparation, lyophilization and reconstitution of a simple semi-synthetic concentrated liquid medium; culture technique, growth pattern of different mycobacteria. Bull. World Health Organ. 29:589-606.

44. Swenson, J.M., R.J. Wallace Jr., V.A. Silcox, and C. Thornsberry. 1985. Antimicrobial susceptibility of five subgroups of $\mathrm{Myco}$ bacterium fortuitum and Mycobacterium chelonae. Antimicrob. Agents Chemother. 28:807-811.

45. Swindell, S.R., and T.N. Plasterer. 1997. SEQMAN. Contig assembly. Methods Mol. Biol. 70:75-89.
46. Tamura, K., J. Dudley, M. Nei, and S. Kumar. 2007. MEGA4: Molecular evolutionary genetics analysis (MEGA) software version 4.0. Mol. Biol. Evol. 24:1596-1599.

47. Thioulouse, J., D. Chessel, S. Dolédec, and J.M. Olivier. 1997. ADE4: a multivariate analysis and graphical display software. Stat Comput. 7:75-83.

48. Tortoli, E. 2003. Impact of genotypic studies on mycobacterial taxonomy: the new mycobacteria of the 1990s. Clin. Microbiol. Rev. 16:319-354.

49. Vaerewijck, M.J.M., G. Huys, J.C. Palomino, J. Swings, and F. Portaels. 2005. Mycobacteria in drinking water distribution systems: ecology and significance for human health. FEMS Microbiol. Rev. 29:911-934.

50. van Ingen J., M.J. Boeree, P.N.R. Dekhuijzen, and D. van Soolingen. 2009. Environmental sources of rapid growing nontuberculous mycobacteria causing disease in humans. Clin. Microbiol. Infect. 15:888-893.

51. Versalovic, J., M. Schneider, F.J. de Bruijn, and J.R. Lupski. 1994 Genomic fingerprinting of bacteria using repetitive sequence-based polymerase chain reaction. Methods Mol. Cell Biol. 5:25-40.

52. Wallace, R.J., J.R. Dalovisio, and G.A. Pankey. 1979. Disk diffusion testing of susceptibility of Mycobacterium fortuitum and Mycobacterium chelonei to antibacterial agents. Antimicrob. Agents Chemoter. 16:611-614.

53. Yamamura, H., and S. Harayma. 2007. Method for selective isolation of mycobacteria using olive oil emulsified with SDS. Biosci. Biotechnol. Biochem. 71:1553-1556. 